The social life of forest carbon: property and politics in the production of a new commodity

\author{
Sango Mahanty, Sarah Milne, Wolfram Dressler, Colin Filer ${ }^{1}$
}

\begin{abstract}
Interventions to conserve carbon stored in forests are central to the emerging global climate change regime. Widely referred to as REDD+, these interventions engage local resource holders in contracts to restrict their use of land and forests in exchange for conditional benefits, effectively creating a market for forest carbon - a new and intangible commodity. Delving into the social and material implications of this, three case studies (Papua New Guinea, Philippines, Cambodia) examine property relations in the early stages of forest carbon production in different tenure contexts. The case studies reveal that: (i) the risk of local exclusion from forest and lands under REDD+ is real, but is mediated by dynamic negotiations over knowledge and property; (ii) the relationship between forest carbon and underlying property relations around land and forests is recursive and mutually constitutive; and (iii) due to ongoing and entrenched property contests in REDD+ locations, there remains an unstable foundation for forest carbon markets.
\end{abstract}

Keywords: property, forest carbon, REDD+, commodity

\footnotetext{
1 Mahanty, Milne and Filer are based in the College of Asia and the Pacific at the Australian National University; Dressler is with the Forests and Nature Conservation Policy Group, Wageningen University. Contact: Sango Mahanty, Resource Management in Asia-Pacific Program, College of Asia and the Pacific, Australian National University, sango.mahanty@anu.edu.au
} 


\title{
1447r1toeditspecialissue
}

\section{The social life of forest carbon: property and politics in the production of a new commodity}

\author{
Sango Mahanty, Sarah Milne, Wolfram Dressler, Colin Filer ${ }^{2}$
}

\section{INTRODUCTION}

Interventions to conserve carbon stored in forests are central to the emerging global climate change regime. Widely referred to as REDD+, these interventions engage local resource holders in contracts to restrict their use of land and forests in exchange for conditional benefits, effectively creating a market for forest carbon - a new and intangible commodity. Delving into the social and material implications of this, three case studies (Papua New Guinea, The Philippines, and Cambodia) examine property relations in the early stages of forest carbon production in different tenure contexts. The case studies reveal that: (i) the risk of local exclusion from forest and lands under REDD+ is real, but is mediated by dynamic negotiations over knowledge and property; (ii) the relationship between forest carbon and underlying property relations around land and forests is recursive and mutually constitutive; and (iii) due to ongoing and entrenched property contests in REDD+ locations there remains an unstable foundation for forest carbon markets.

Tropical deforestation and forest degradation in the developing world contribute some 15\% of global greenhouse gas emissions (Van der Werf et al. 2009). As a means to address this, key international organisations, national governments, and the private sector have adopted the contentious approach of using market-based mechanisms to arrest forest loss and conserve carbon. Amongst the suite of measures under discussion to reduce emissions from deforestation and forest degradation (known collectively as REDD+), the use of performancebased payments and voluntary markets is central (Peskett and Brockhaus 2009). These measures effectively create a market for the carbon stored in trees and forests (Kosoy and Corbera 2010; Bumpus 2011), giving rise to the new, intangible commodity of forest carbon.

A commodity's "social life" encompasses the situations that mediate its production, exchange and eventual consumption at different locations and times (Appadurai 1986: 13). The embryonic (verging on hypothetical) global arrangements for forest carbon exchange and consumption leads us to focus this special issue on the production stage of its social life,

\footnotetext{
${ }^{2}$ Mahanty, Milne and Filer are based in the College of Asia and the Pacific at the Australian National University; Dressler is with the Forests and Nature Conservation Policy Group, Wageningen University. Contact: Sango Mahanty, Resource Management in Asia-Pacific Program, College of Asia and the Pacific, Australian National University, sango.mahanty@anu.edu.au
} 
including the situations, materials and labour on which forest carbon production and exchange depends. Transforming forest carbon into a commodity requires its privatisation, its individuation or delineation into individual units for trade ${ }^{3}$, its valuation in monetary terms, and finally its displacement from the labour and resource context in which it was 'produced' (Castree 2003). The resulting commodity chain for forest carbon, which appears as an intangible unit for exchange, ties its production back to the material realm (forests, land and labour), whose benefits and risks are distributed through socio-political and economic relations and institutions, from the local to the international level (Ribot 1998).

The deep social, political and economic significance of land and forests (Polanyi 2001 [1944]; Hall et al. 2011; Tsing 2005) lends urgency to the analysis of these material foundations of forest carbon. A key concern is the risk that existing local claims and rights to forests, including dynamics of "intimate exclusion" (Hall et al. 2011: 145), may be overridden by newly emerging rights to forest carbon, as states reassert control of increasingly valuable forests that serve as carbon reservoirs (Phelps et al. 2010; Sikor et al. 2010). This could in turn lead to diminished livelihoods through new restrictions on traditional land use practices, such as swidden. The most marginal local actors might then bear the costs of REDD+ while the benefits flow to governments and national and local elites (Ghazoul et al. 2010). Relatedly, the property rights for forest carbon are ill-defined and contested, with struggles over the pricing and distribution of benefits. It is in most cases premature to determine the livelihood impacts of forest carbon markets. However, it is possible and timely to analyse how the social relations of forest carbon production are evolving. The three cases presented in this issue contribute new insights into the relationship between forest carbon and the socially, culturally and economically valuable land and forests that are required for its production.

The nexus between forest carbon and existing land and forest property leads some scholars to cite clear property rights as a "killer condition" not only for the effective functioning of contracts to sell and purchase ecosystem services (Wunder 2009), but also to return benefits to local right-holders (Sunderlin et al. 2009; Larson 2011). Some further suggest that only countries with clear property rights that duly recognise customary claims, should be prioritized as "REDD countries" (Phelps et al. 2010). The three papers that follow ask whether, as these scholars suggest, an environment with recognised and strong customary tenure is somehow more "REDD+ ready" relative to cases with weak local tenure. The three cases, in Papua New Guinea (PNG), The Philippines and Cambodia, are examined to establish the influence of constitutionally recognised customary tenure and ancestral domain (in PNG and The Philippines), and informally 'tolerated' customary claims (Cambodia) on forest carbon and REDD-related negotiations.

The other side of this equation is the question of whether and how the production of forest carbon influences prior property relations around land and forests. Is the feared exclusion of

\footnotetext{
${ }^{3}$ This unit is known as the 'carbon credit' - a formally certified unit whose purchase allows the buyer to offset or reduce emissions by one metric ton of carbon dioxide (Bumpus and Liverman 2008)
} 
the most marginal local actors from the critical livelihood resources of land and forests being realised, or do strong local rights at the outset lessen this risk?

\section{COUNTRY CASE STUDIES}

\section{Papua New Guinea}

Of the three countries examined in this set of case studies, Papua New Guinea is the one in which community land and forest tenure has the strongest formal recognition. It is commonly asserted that $97 \%$ of PNG's land area and $99 \%$ of its native forests belong to customary landowners or indigenous communities. However, this apparent tenure security has been transformed in two ways, first through a process by which timber harvesting rights have been alienated for the establishment of selective logging concessions, and more recently through a process by which customary rights have been alienated for the purpose of forest clearance and agricultural development (Filer 2012). The case study by Wood and Filer illustrates how the prospect of profits from forest carbon interacts with these property dynamics and configurations, leading to new kinds of struggles over land and forests and the emergence of new types of 'agents' and resources.

The PNG case study is based on empirical material drawn from the authors' observations of two related phenomena over the period since 2005. First is the national REDD policy process in PNG, in which high-level jostling for control over the means of production of forest carbon emerged, especially in relation to knowledge about how to measure and demonstrate carbon credits, and authority over REDD-related decision-making and contractual arrangements. These struggles over knowledge and authority at the national level effectively created a new layer of property relations around forests and land in PNG in which 'bureaucratic shifting' was employed by certain state actors in order to establish and maintain control over the carbon economy as part of a broader government monopoly over decisions about the use of forested land. The second phenomenon is the interaction between different claims over forests at the regional scale in a location where property contests have been especially intense. At both political scales, the appropriation of forest carbon has been rendered problematic by alternative forms of commoditization.

\section{Philippines}

The Philippines case study by Dressler et al. provides cautionary insights into how the REDD+ policy process is likely to interact with property regimes that are contested or changing, and consist of mixed tenurial forms. Forested landscapes of the Philippines provide a vivid illustration of this. For example, formal legislation for indigenous resource rights has been in place since 1997, in theory enabling ancestral domain claims and title, but this is yet to be fully implemented and is still under negotiation in many areas. Thus, as the case study illustrates, the production of forest carbon in the Philippines will necessarily entail a feat of 'institutional bricolage' (Cleaver 2002) through which formal and informal property rights regimes will need to be combined and synthesised. 
Drawing from observations of early REDD+ implementation on the forest frontier island of Palawan, the case study focuses on how the processes of 'tenurial bricolage' are unfolding in this location. The REDD+ initiative in question is being implemented by a range of actors from local and national government, international non-government organisations, and indigenous representatives. Their interactions in the course of the REDD+ preparatory phase provide key insights into the property struggles invoked by forest carbon production. In particular, state actors are apparently well positioned to use the new negotiating space opened by REDD+ to strengthen their own property claims and increase their authority over forested land, as seen in the context of decentralisation reforms elsewhere (Ribot et al. 2006). This implies a strengthening of formal state institutions and 'visions' for forest management through REDD+, particularly 'community-based' initiatives, which will inevitably overlay and modify indigenous practices and regimes such as swidden agriculture. The case study demonstrates how this process will have both social and material consequences for local indigenous people, but with uncertain outcomes for livelihoods and landscapes. Ultimately, the authors argue, the outcomes will depend upon the 'relational nature' of the new commodity.

\section{Cambodia}

Milne's case study from Cambodia offers a more grounded view of property relations in the context of forest carbon through a detailed analysis of the implementation of one REDD-like scheme that has been in place since 2006. This scheme, implemented by an international conservation organisation in partnership with the Cambodian Forestry Administration, involves contracts for avoided deforestation that are brokered at the community level. These contracts follow the "opportunity cost approach" to REDD (World Bank Institute 2011), whereby local communities are compensated for the costs that they incur by not cutting forest. The case study demonstrates how this apparently straightforward approach in practice involves complex interventions in property, including land-use mapping, forest demarcation and valuation of benefits derived from forest and land by local communities. By exploring the social and political dynamics of these processes, key aspects of the social life of forest carbon production are revealed, along with the potentially ephemeral nature of this new commodity.

The scheme's underlying property relations or 'initial conditions' reflect the wider Cambodian context very closely. That is, forested land is considered to be state property, while customary resource use by indigenous and local communities is either partially recognised under the Forestry Law or 'tolerated' on a de facto basis. This tenure scenario contrasts significantly with that of Papua New Guinea and The Philippines, offering little prospect for REDD+ that is based on formal property rights held by communities. However, the Cambodian case instead reveals how contracts for avoided deforestation can be negotiated on the basis of informal or customary rights. This approach may well become a feature of REDD+ in developing countries in the short term (Streck 2009), but the case study reveals its problematic side-effects. In particular, a 'property paradox' emerges whereby customary resource rights are simultaneously recognised through compensation payments, yet taken away through required behaviour change for avoided deforestation purposes. Thus, the 
production of forest carbon can modify underlying property relations in contradictory ways, with unknown consequences.

\section{KEY INSIGHTS AND FINDINGS}

The cases demonstrate how underlying tenure regimes influence the evolution of forest carbon markets, such that even the strongest forms of customary tenure may still provide a highly contested and unsteady basis for REDD+. Even in contexts such as PNG and The Philippines, where tenure is believed to be settled and well delineated, existing property contests create uncertain ground for forest carbon markets. At the same time, the opportunity to trade forest carbon creates new stakes, with actors vying to command the land and forests required for its production. Where rights are weak, as in Cambodia, there is excitement about the prospect of strengthening local rights to forests and land through forest carbon agreements. However, the Cambodian case illustrates the inherently paradoxical nature of such rights, which come with firm restrictions on how they may be exercised. In all three cases, there is a mutually constitutive relationship between forest carbon and the underlying property relations in the localities where carbon production takes root.

The implications of REDD+ for local access to or exclusion from land and forests depend strongly on the actors involved, how they lay claim to forests, land and forest carbon, and the interplay of such claims across scales. Here, knowledge plays a central role in production, particularly because of the intangible nature of forest carbon (Appadurai 1986; Bumpus and Liverman 2008). This interplay of claims, strategies and knowledge is most clearly seen in the case of PNG, where knowledge politics and local exclusion from policy processes has rendered landowners impotent as actors in forest carbon markets, and in The Philippines, where tenure design and incentives for avoided deforestation are strongly shaped by the political culture of the state and civil society. Thus, beyond formal tenure arrangements, power relations and knowledge are central mediating factors in access to and exclusion from forest carbon and its underlying material resources.

While it is too early in these three countries to assess the livelihood impacts of forest carbon markets, studying property relations in the production of forest carbon yields important insights. In all three cases various forms of exclusion are emerging in relation to the productive resources required for forest carbon production and from the knowledge negotiations that will be central to carbon trade. These papers therefore provide an early indication of the risks connected with forest carbon trade for local property relations and associated livelihoods. While focusing on forest carbon production, we are conscious that the remaining 'global connections' (Tsing 2005) - the networks of trade and consumption that comprise forest carbon's social life - still remain to be explored as the carbon market takes form.

\section{REFERENCES}


Appadurai, A. (1986) Introduction: commodities and the politics of value. in Appadurai, A. (Ed.) The Social Life of Things: commodities in cultural perspective. Cambridge, Cambridge University Press, pp. 3-63.

Bumpus, A. G. (2011) The Matter of Carbon: Understanding the Materiality of $\mathrm{tCO}_{2} \mathrm{e}$ in Carbon Offsets. Antipode. 43 (3): 612-638.

Bumpus, A. G. \& Liverman, D. M. (2008) Accumulation by Decarbonization and the Governance of Carbon Offsets. Economic Geography. 84 (2): 127-155.

Castree, N. (2003) Commodifying what nature? Progress in Human Geography. 27 (3): 273 297.

Cleaver, F. (2002) Reinventing Institutions: Bricolage and the Social Embeddedness of Natural Resource Management. The European Journal of Development Research. 14 (2): 11-30.

Filer, C. (2012) Why green grabs don't work in Papua New Guinea. Journal of Peasant Studies. 39 (2): 599-617.

Hall, D., Hirsch, P. \& Li, T. M. (2011) Powers of Exclusion: land dilemmas in Southeast Asia. Singapore, NUS Press.

Kosoy, N. \& Corbera, E. (2010) Payments for ecosystem services as commodity fetishism. Ecological Economics 69 ): 1228-1236.

Larson, A. M. (2011) Forest tenure reform in the age of climate change:Lessons for REDD+. Global Environmental Change. 21 (2): 540-549.

Peskett, L. \& Brockhaus, M. (2009) When REDD+ goes national: A review of realities, opportunities and challenges. in Angelsen, A., with Brockhaus, M., Kanninen, M., Sills, E., Sunderlin, W. D. \& Wertz-Kanounniko, S. (Eds.) Realising REDD+National strategy and policy options. Bogor, Indonesia, CIFOR,

Phelps, J., Guerrero, M. C., Dalabajan, D. A., Young, B. \& Webba, E. L. (2010) What makes a "REDD" country? Global Environmental Change. 20 (2): 322-332.

Phelps, J., Webb, E. L. \& Agrawal, A. (2010 ) Does REDD+ Threaten to Recentralize Forest Governance? Science. 328 (16 April 2010): 312-313.

Polanyi, K. (2001 [1944]) The Great Transformation: the political and economic origins of our time. Boston, MA, Beacon Press.

Ribot, J., Agrawal, A. \& Larson, A. (2006) Recentralising while decentralizing: How national governments reappropriate forest resources. World Development. 34 (11): 1864-1886.

Ribot, J. C. (1998) Theorizing Access: forest profits along Senegal's charcoal commodity chain. Development and Change. 29 (1998): 307-341.

Sikor, T., Stahl, J., Enters, T., Ribot, J., Singh, N., Sunderlin, W. \& Wollenberg, L. (2010) REDD-plus, forest people's rights and nested climate governance. Global Environmental Change. 20 (3): 423-425. 
Streck, C. (2009) Rights and REDD+: legal and regulatory considerations. in Angelsen, A. (Ed.) Realising REDD+: National strategy and policy options. Bogor, CIFOR, pp. 151-162.

Sunderlin, W. D., Larson, A. M. \& Cronkleton, P. (2009) Forest tenure rights and REDD+: From inertia to policy solutions. in Angelsen, A., Brockhaus, M., Kanninen, M., Sills, E., Sunderlin, W. D. \& Wertz-Kanounniko, S. (Eds.) Realising REDD+National strategy and policy options. CIFOR, Bogor, Indonesia., pp. 139-150.

Tsing, A. L. (2005) Friction: An ethnograhy of global connection. Princeton and Oxford, Princeton University Press.

Van der Werf, G. R., Morton, D. C., Defries, R. S., Olivier, J. G. J., Kasibhatla, P. S., Jackson, R. B., Collatz, G. J. \& Randerson, J. T. (2009) CO2 emissions from forest loss. Nature Geoscience. 2): 737-738.

World Bank Institute (2011) Estimating the opportunity costs of REDD+: A training manual. in. Washington DC, The World Bank. 


\section{University Library}

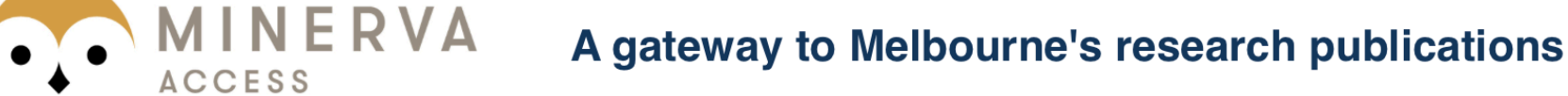

Minerva Access is the Institutional Repository of The University of Melbourne

Author/s:

Mahanty, S;Milne, S;Dressler, W;Filer, C

Title:

The Social Life of Forest Carbon: Property and Politics in the Production of a New Commodity

Date:

2012-10-01

Citation:

Mahanty, S., Milne, S., Dressler, W. \& Filer, C. (2012). The Social Life of Forest Carbon: Property and Politics in the Production of a New Commodity. HUMAN ECOLOGY, 40 (5), pp.661-664. https://doi.org/10.1007/s10745-012-9524-1.

Persistent Link:

http://hdl.handle.net/11343/282596 